http://dx.doi.org/10.18778/7969-549-2.05

Jakub Niedbalski

Uniwersytet Łódzki

\title{
Praktyczne zastosowanie oprogramowania CAQDA w badaniach jakościowych - zarys problematyki z perspektywy projektu badawczego opartego na metodologii teorii ugruntowanej ${ }^{1}$
}

Streszczenie. Celem artykułu jest ukazanie, w jaki sposób można wykorzystać narzędzia komputerowego wspomagania analizy danych jakościowych w praktyce badawczej. Na przykładzie konkretnego projektu badawczego autor stara się przybliżyć, jak realizować badania zgodnie z procedurami metodologii teorii ugruntowanej, korzystając z dostępnych funkcji programów Audacity, WeftQDA oraz CmapTools. W ten sposób ukazany zostaje warsztat badacza jakościowego stosującego na co dzień oprogramowanie komputerowe wspomagające proces badawczy. W artykule można zobaczyć, jak kształtuje się proces analityczny w kontekście wybranej metody i przy zastosowaniu określonego rodzaju oprogramowania komputerowego. Autor wskazuje zarówno na istniejące udogodnienia, konsekwencje stosowania programów komputerowych, jak i potencjalne trudności związane ze stosowaniem CAQDA w badaniach jakościowych. Artykuł ma charakter poglądowy i edukacyjny, pozwalający zapoznać się czytelnikowi z możliwościami narzędzi CAQDA oraz ich faktycznym zastosowaniem w realizacji projektów badawczych opartych na metodach jakościowych.

Słowa kluczowe: komputerowa analiza danych jakościowych, CAQDA, metody badań jakościowych, metodologia teorii ugruntowanej, Audacity, WeftQDA, CmapTools.

\section{Wstęp}

Celem artykułu jest pokazanie, jak przy wykorzystaniu trzech programów komputerowych dostępnych nieodpłatnie można przeprowadzić najważniejsze czynności związane z formalnym przygotowaniem danych, ich opracowaniem oraz analizą zgodnie z procedurami metodologii teorii ugruntowanej (MTU) oraz zwizualizowaniem zarówno bieżących ustaleń badacza, jak i końcowych wyników analizy w postaci diagramu integrującego, pokazującego wygenerowane

\footnotetext{
${ }^{1}$ Tekst został opracowany na podstawie informacji zawartych w książce Niedbalskiego (2013).
} 
kategorie i relacje między nimi. Zadaniem artykułu jest pokazanie zalet, ale i pewnych ograniczeń związanych z zastosowaniem wybranych programów komputerowych.

Opisane programy zostały dobrane celowo tak, aby wzajemnie się dopełniały w zakresie oferowanych przez nie funkcji, w kontekście realizacji badań opartych na procedurach metodologii teorii ugruntowanej (Glaser, Strauss 1967; Glaser 1978; Strauss, Corbin 1990; Charmaz 2009). Nie oznacza to jednak, że informacje opisane $w$ artykule mogą się przydać wąskiej grupie badaczy, bowiem zaprezentowane programy mogą być z powodzeniem stosowane w ramach badań opartych na innych metodach badawczych niż MTU. W przypadku metodologii teorii ugruntowanej korzystamy głównie z danych, które są po pierwsze nieustrukturyzowane, po drugie występują najczęściej w postaci tekstowej i po trzecie - pozyskiwane są za pomocą takich technik badawczych, jak wywiady bądź obserwacje. Ponieważ zatem tekst odgrywa kluczową rolę w analizie opartej na MTU (oczywiście nie sposób pominąć innych współcześnie rozwijanych odmian opisywanej metodologii i związanych z tym faktem rozmaitymi rodzajami danych w postaci m.in. obrazu - Konecki 2008), to właśnie na nim powinna skoncentrować się nasza uwaga. Przemawia za tym zresztą jeszcze jeden, stricte techniczny argument - prezentowane programy umożliwiają przede wszystkim analizę plików tekstowych. To niejako wyklucza możliwość stosowania danych innego rodzaju. Jednak, jak już wspomniano, to właśnie dane tekstowe są zasadniczym źródłem informacji poddawanych analizie w ramach MTU. Może to niejako również usprawiedliwiać nacisk, jaki autor położył na programy obsługujące właśnie ten rodzaj danych. Niemiej w pewnym, choć w uproszczonym, zakresie można też przy pomocy opisanych programów prowadzić prostą analizę danych audio oraz danych wizualnych. Te pierwsze będą obsługiwane przez Audacity (w przypadku którego można dodawać etykiety do fragmentów ścieżki dźwiękowej), drugie zaś można włączać w budowaną mapę pojęciową, używając programu CmapTools (gdzie można stosować zdjęcia jako wizualizacje dla elementów mapy pojęciowej). Jednak ze względu na istotne ograniczenia, jakie wiążą się ze stosowaniem danych tego rodzaju, możliwości wspomnianych programów w tym zakresie zostaną jedynie zarysowane. Główny nacisk zostanie natomiast położony na przygotowanie i analizę danych tekstowych. Choć i w tym przypadku należy zaznaczyć, że dane tekstowe muszą być sformatowane $w$ wersji .txt, a więc nie ma możliwości stosowania m.in. wielu rodzajów czcionki, jej krojów itd. (mimo to pewne niuanse wypowiedzi można z powodzeniem oddać, stosując system znaków diakrytycznych). Nie da się też przenosić danych pomiędzy programami, przez co poszczególne czynności muszą być wykonywane, przynajmniej częściowo, odrębnie w ramach każdego programu. 
Zaprezentowane programy, pomimo pewnych ograniczeń, mogą jednak dzięki posiadanym funkcjom znacznie poprawić komfort pracy badacza i przyczynić się do sprawniejszego, a być może także lepszego (choć to zależy przede wszystkim od samego badacza i jego umiejętności analitycznych oraz posiadanej wiedzy), opracowania danych i uzyskania na ich podstawie satysfakcjonujących wniosków.

\section{Podstawowe wymogi stawiane przez metodologię teorii ugruntowanej}

Dzięki opisywanym w artykule programom możemy zrealizować badania oparte na metodologii teorii ugruntowanej i w znacznej mierze pozostać w zgodzie z jej wymogami. Nim więc przystąpimy do zaprezentowania dostępnych w programach funkcji, spróbujmy naszkicować, nawet w bardzo ogólnym zakresie, podstawowe procedury, na jakich opiera się MTU. Z tego względu poniżej przedstawiona została ogólna charakterystyka metodologii teorii ugruntowanej, która jako metoda badań posiada pewien system reguł dotyczących organizowania określonej działalności badawczej, tj. szeregu operacji poznawczych i praktycznych, kolejności ich zastosowania oraz specjalnych środków i działań skierowanych z góry na założony cel badawczy (Łobocki 1978: 115; Sztumski 1979: 55).

Metodologia teorii ugruntowanej polega na budowaniu teorii (średniego zasięgu) na podstawie systematycznie zbieranych danych empirycznych (zob. Glaser, Strauss 1967; Glaser 1978). Teoria jest tu pochodną analizy danych (Charmaz 2009: 90).

Badacz, który decyduje się na użycie metodologii teorii ugruntowanej, powinien, na ile jest to tylko możliwe, wystrzegać się konstruowania wstępnych założeń, które mogą spowodować, że niechybnie stanie się „niewolnikiem teorii”. Zaleca się, aby, przystępując do badań, w największym stopniu ograniczył prekonceptualizację własnych zamierzeń badawczych (Konecki 2000: 26; Frankfort-Nachmias, Nachmias 2001: 313). Równocześnie należy pamiętać, że wymóg ograniczenia prekonceptualizacji nie jest równoznaczny z separacją od jakichkolwiek podstaw teoretycznych i posiadanej już wiedzy z zakresu interesującego nas obszaru badań. Zgodnie z tym wymogiem w początkowej fazie badań badacz powinien przede wszystkim koncentrować się na szczegółowym opisie zebranego materiału empirycznego, a dopiero potem formułować twierdzenia teoretyczne (Konecki 2000: 26-27). Wiedza teoretyczna oraz informacje dotyczące eksplorowanego środowiska, które posiadał badacz przed przystąpieniem do pracy badawczej, mogą okazać się pomocne w dalszych jej etapach, służąc między innymi jako dane porównawcze oraz wskazówki przy teoretycznym doborze próbek (Strauss, Corbin 1990: 48-56; Glaser 1978: 67). 
Proces zbierania danych empirycznych, w przypadku zastosowania MTU, odbywa się nie stadialnie, fazowo, lecz łącznie z prowadzoną równolegle analizą i interpretacją. Teoria wyłania się tutaj w trakcie systematycznie prowadzonych badań empirycznych (Konecki 2000). A zatem proces zdobywania, analizy i interpretacji danych stanowi integralną, przebiegającą w jednym czasie, część całego procesu badawczego, podczas którego wykorzystywane są określone procedury metodologiczne, m.in. teoretyczne pobieranie próbek (theoretical sampling) i teoretyczne nasycenie (theoretical saturation). Zastosowanie procedur metodologii teorii ugruntowanej powoduje, że proces zbierania danych empirycznych nie będzie przebiegał w sposób zupełnie przypadkowy, lecz zostanie oparty na określonej strategii doboru danych, porządkującej stale gromadzony materiał.

Metodologia teorii ugruntowanej oferuje procedurę teoretycznego pobierania próbek (theoretical sampling), dzięki której badacz, zbierając, kodując i analizując materiały, równocześnie na bieżąco decyduje, gdzie i jakiego rodzaju dane w dalszym ciągu gromadzić (Glaser, 1978: 49-50; Strauss, Corbin 1990: 177). Badacz, napotykając podczas swojej pracy terenowej na interesujące go zjawiska, może zmienić tok i zakres poszukiwań, koncentrując swoją uwagę na takich aspektach, których wcześniej nie brał pod uwagę bądź, z których istnienia nie zdawał sobie w ogóle sprawy (Konecki 2000: 30). Pobieranie próbek ma charakter procesualny i odbywa się do chwili osiągnięcia teoretycznego nasycenia (theoretical saturation), a więc takiego momentu, w którym nie pojawiają się już żadne nowe dane, a kolejne przypadki są podobne do wcześniejszych i można je zanalizować za pomocą już istniejących kategorii (Glaser 1978: 142).

Inną, równie ważną strategią MTU jest metoda ciągłego porównywania (constant comparative method). Badacz w poszukiwaniu kolejnych danych do porównań stara się dobierać zarówno bardzo różne, jak i podobne do siebie przypadki, by uchwycić maksymalnie dużo warunków różnicujących występowanie kategorii oraz ich wzajemnych powiązań (Glaser 1978: 45-53; Charmaz 2009: 74).

Metodologia teorii ugruntowanej stwarza możliwość dotarcia do perspektywy aktorów społecznych i uchwycenia procesualnego wymiaru badanych zjawisk (Glaser 1978: 11), a dzięki liberalnemu traktowaniu źródeł danych daje możliwość posiłkowania się badacza każdym rodzajem informacji.

\section{Przygotowanie danych do analizy za pomocą programu Audacity}

Przed przystąpieniem do analizy danych badacz musi dokonać stosownej „obróbki”, a więc przygotowania wcześniej pozyskanych materiałów. Ponieważ w wielu przypadkach materiał taki będzie pochodził z wywiadów zazwyczaj utrwalonych na różnych nośnikach plików audio, stąd niejako konieczny staje 
się proces ich przełożenia w możliwie najwierniejszy sposób na formę tekstową, a więc transkrypcja (Rapley 2010: 104-105). Dużym ułatwieniem są nowoczesne zdobycze techniki. Dzięki nim badacz wyposażony zostaje w niezwykle pomocne narzędzia, znacznie przyspieszające ów proces przygotowania danych. Dzisiaj w powszechnym użyciu są urządzenia umożliwiające nagrywanie dźwięku w postaci cyfrowej. Ma to duże znaczenie z perspektywy pracy badacza, bowiem pozwala nie tylko na wykonywanie dobrej jakości nagrań czy łatwy sposób ich archiwizowania, lecz przede wszystkim umożliwia dużo prostsze ich transkrybowanie. Takie możliwości daje bardzo wiele powszechnie używanych przez nas urządzeń, jak chociażby telefony komórkowe czy smartfony. Jednak profesjonalna praca badacza wymaga narzędzi stworzonych typowo z myślą o nagrywaniu dźwięku, a więc dyktafonów. Maję one tę przewagę nad innymi urządzeniami, że pozwalają na ustawianie wielu rozmaitych parametrów poprawiających jakość nagrania, a po wtóre ich konstrukcja jest tak pomyślana, aby jak najlepiej „zbierały” konkretne dźwięki interesujące badacza. Warto wspomnieć, że obecnie korzystając z tego typu urządzeń, mamy też możliwość zainstalowania i użytkowania dołączonych do nich specjalnych programów służących nie tylko zgrywaniu dźwięku lub zmianie formatu, lecz także ich wyposażeniu w opcje pomocne podczas przepisywania. Niemniej są to przeważnie narzędzia dość proste, które nie pozwalają na bardziej złożone operacje na plikach audio. Jeśli zatem badacz chciałby skorzystać z nieco bardziej wyrafinowanych narzędzi, wyposażonych w konkretne, pomocne podczas transkrypcji opcje, wówczas musi szukać odpowiednich dla tego celu programów komputerowych. Ich paleta sukcesywnie rośnie, jednak w przeważającej części są to programy licencjonowane, których zakup wymaga posiadania określonych środków finansowych. $Z$ tego względu nie każdy może sobie pozwolić na ich zakup, tak jak i na ewentualne zlecenie transkrypcji innym osobom bądź wyspecjalizowanym w tej dziedzinie podmiotom, a więc firmom oferującym tego rodzaju usługi. Na szczęście istnieją dostępne dla wszystkich rozwiązania alternatywne w postaci bezpłatnego, a zarazem posiadającego specjalne możliwości oprogramowania komputerowego przeznaczonego do transkrypcji danych. Takim narzędziem jest program Audacity², który został wyposażony w kilka interesujących i przydatnych funkcji, znacznie wspomagających i przyspieszających ów żmudny proces.

Na szczególną uwagę zasługuje pasek narzędziowy transkrypcji, dzięki któremu możliwe jest odtwarzanie dźwięku z mniejszą lub większą szybkością w zależności od potrzeb użytkownika. Prędkość odtwarzania dźwięku regulujemy suwakiem. Gdy przesuwamy go w prawo, w kierunku plusa, wówczas powodujemy

${ }^{2}$ Program powstał z inicjatywy Dominica Mazzoniego i jest rozwijany przez Zespół Audacity. Program oraz dodatkowe informacje o nim można pobrać ze strony: http://audacity.sourceforge. net/download/. 
przyspieszenie, gdy zaś w lewo, w kierunku minusa, spowolnienie odtwarzania nagrania. Prędkość normalna to wartość 1.00, poniżej tej wartości prędkość odtwarzania będzie mniejsza (np. 0.01x oznacza jedną setną normalnej prędkości), zaś powyżej, prędkość odtwarzania jest większa (np. 3.00x oznacza trzykrotne przyspieszenie odtwarzania nagrania). Aby ustawić dokładną prędkość odtwarzania nagrania, należy dwa razy kliknąć na suwak na pasku narzędzi transkrypcji, a w otwartym w ten sposób oknie wpisać konkretną wartość prędkości (Niedbalski 2013: 55).

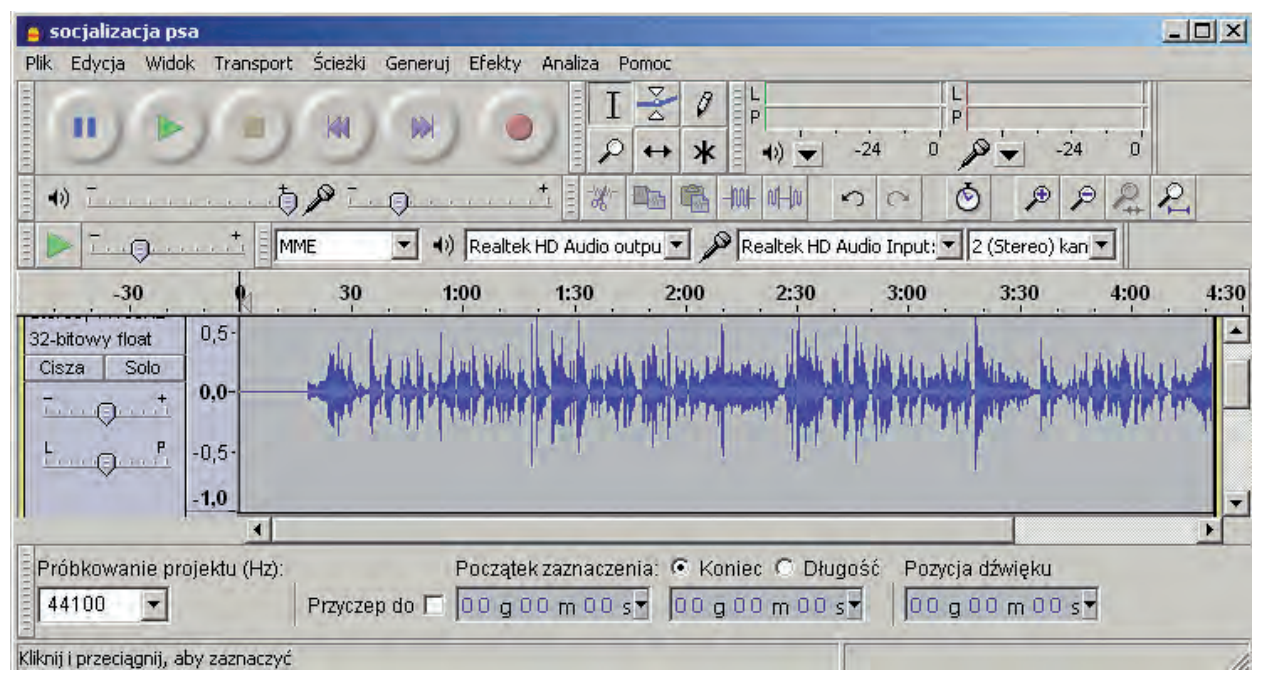

Ilustr. 1. Okno programu Audacity

Źródło: opracowanie własne

Pewną wadą opisanej opcji jest to, że nie można zmieniać w sposób płynny, tj. podczas odtwarzania pliku, prędkości nagrania, przesuwając suwak w lewo lub w prawo. Aby zmienić prędkość odtwarzania, należy zatem wybrać żądaną wartość prędkości i nacisnąć przycisk Odtwórz na pasku narzędzi transkrypcji. Przy czym jego naciśnięcie oznacza odtwarzanie nagrania od początku (bądź od zaznaczonego uprzednio punktu).

Dużym ułatwieniem przy transkrybowaniu może być również ustawienie powtarzającego się odtwarzania fragmentu nagrania (odtwarzania w pętli). Kilkukrotne przesłuchiwanie tego samego "kawałka” wywiadu bez potrzeby ciągłego włączania, wyłączania oraz cofania nagrania nie tylko ułatwi nam pracę i wpłynie na jakość transkrypcji, lecz także skróci czas jej wykonywania. Aby skorzystać z tej funkcji, należy z menu Transport wybrać pozycję Odtwórz w pętli! bądź użyć skrótu klawiaturowego Shift + Space (można także klikając na Play, przytrzymać przycisk Shift). 
Program posiada bardzo rozbudowany repertuar efektów, których użycie będzie modyfikowało zapis audio. Wśród nich znalazły się takie, które mogą służyć osobie pracującej z nagraniami wywiadów. Warto zwrócić uwagę zwłaszcza na te opcje, które służą poprawie jakości nagrania. W przypadku badacza stosującego materiały dźwiękowe ma to jeszcze większe znaczenie, gdy nagrania nie są najlepszej jakości i posiadają defekty, utrudniające rozszyfrowanie sensu wypowiedzi rozmówcy. Wśród narzędzi, które mogą rozwiązać problem trudności W „rozszyfrowaniu” zapisu dźwięku, jest na pewno odszumiacz (Usuń szum...). Służy on do usuwania, a przynajmniej zmniejszania szumów otoczenia, jakie mogą się pojawić w nagraniu. Przy czym oznacza to, że możemy dość skutecznie zneutralizować jakieś wyraźnie słyszalne dźwięki typu gwizdek, skomlenie psa czy buczenie dzwonka, jednak znacznie trudniej będzie usunąć nieregularny hałas, spotykany na przykład w ruchu publicznym. Innym pomocnym narzędziem służącym poprawie jakości dźwięku nagrania jest opcja Usuwania stukotu..., która pomaga w korygowaniu nagrania poprzez zmniejszanie słyszalnych trzasków (podobnych do tych, jakie można usłyszeć przy odtwarzaniu płyty winylowej) oraz stukotów czy kliknięć (Niedbalski 2013: 58-60).

Podkreślić trzeba, że proces przygotowawczy, w tym transkrypcja danych, mogą być, w zależności od przyjętej metodologii badawczej, częścią samej analizy. Co więcej, sama czynność transkrybowania jest przekształcaniem formy danych badawczych, co jednak nierzadko wiąże się z ich modyfikowaniem, a do pewnego stopnia także interpretowaniem (Bielecka-Prus 2013; Niedbalski 2014). Tym bardziej warto zwrócić uwagę na jeszcze jedną funkcję dostępną w programie, a mianowicie możliwość tworzenia etykiet. Zwłaszcza dla osoby korzystającej z Audacity jako narzędzia do transkrybowania wywiadów, opcja ta wydaje się szczególnie przydatna. Etykiety mogą służyć do tego, aby w formie adnotacji zaznaczyć fragmenty, które są naszymi pytaniami oraz te, które są odpowiedziami respondenta, ale także po to, aby za ich pomocą prowadzić prosty system kodowania. Dzięki temu możemy łatwiej poruszać się po materiale, szybciej odszukać interesujące nas fragmenty, ale także podjąć pierwsze próby kodowania bezpośrednio na pliku dźwiękowym.

Od strony technicznej warto zaznaczyć, że etykiety można dodawać na kilka sposobów, a można to czynić zarówno po przesłuchaniu danego fragmentu, jak i bezpośrednio podczas odsłuchiwania nagrania. Ponadto użytkownik może dokonywać różnych modyfikacji etykiet (w tym wpisywać nazwy etykiet, używając polskich liter) za pomocą edytora etykiet. Aby go otworzyć, wchodzimy do menu Ścieżki i wybieramy pozycję Edit Labels... Spowoduje to otwarcie okna dialogowego, w którym będziemy mogli między innymi nadawać nazwy etykietom lub je zmieniać i poprawiać, ponadto ustalać ich początek i koniec, a także korzystać z opcji importowania i eksportowania etykiet (Niedbalski 2013: 46). 


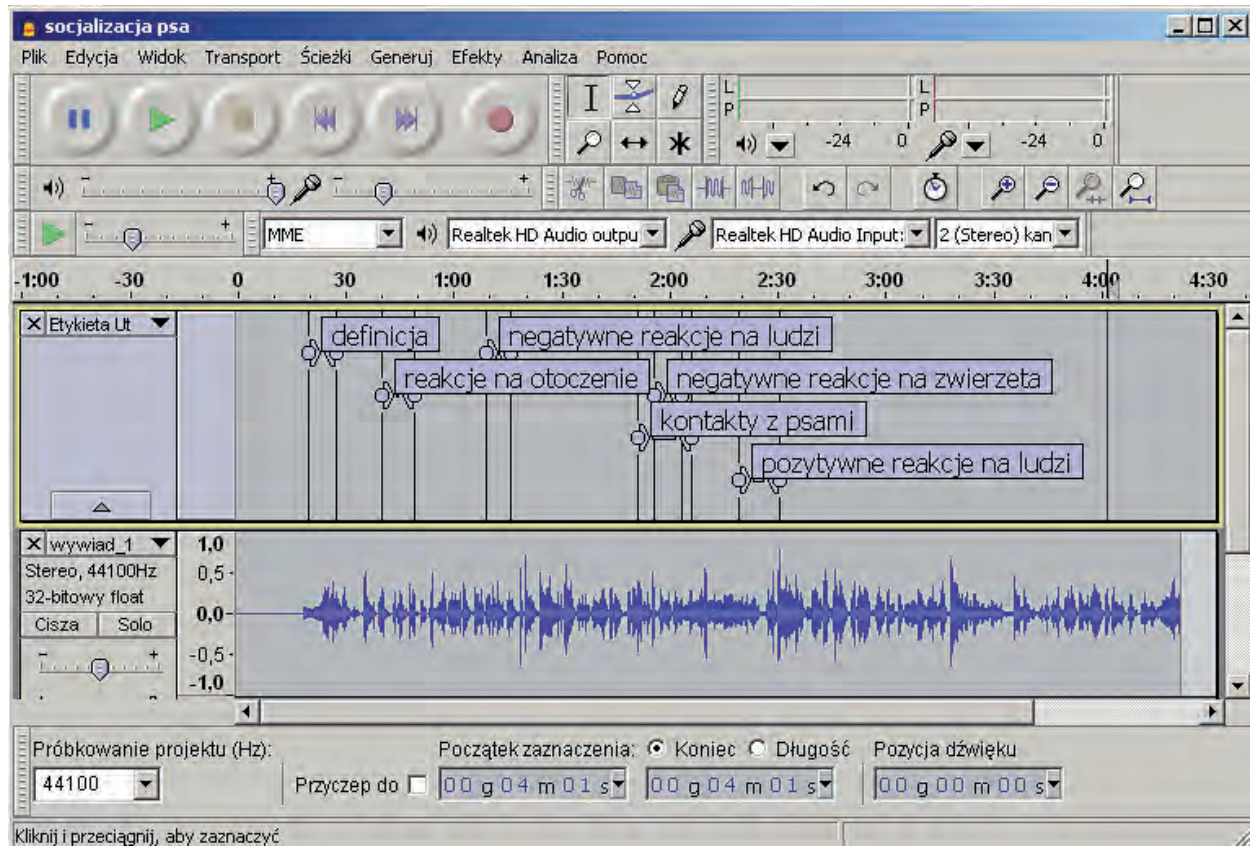

Ilustr. 2. Etykiety przypisane do fragmentów ścieżki dźwiękowej w programie Audacity Źródło: opracowanie własne

Audacity to narzędzie uniwersalne, które posiada funkcje przydatne badaczom jakościowym. W miarę jego rozwoju program doczekał się specjalnych opcji wspomagających proces transkrypcji nagrań audio. Jest to więc narzędzie, które przy odrobinie wysiłku ze strony nowego użytkownika przyczyni się do poprawy wydajności jego pracy.

\section{Analiza danych z wykorzystaniem programu WeftQDA}

Posiadając już odpowiednio opracowane dane, a więc przetranskrybowane pliki audio nagrań przeprowadzonych wywiadów, badacz może przystąpić do ich analizy. Należy przy tym pamiętać, że już podczas przepisywania danych badacz może, przesłuchując wywiad, „wpaść" na jakiś interesujący pomysł, a pewne fragmenty czy konkretne słowa rozmówcy mogą wydawać mu się szczególnie istotne z perspektywy opracowywanego przez niego problemu. Nic nie stoi jednak na przeszkodzie, aby takie informacje zostały przez badacza zapisane. Pomocne mogą być tutaj wspomniane wcześniej etykiety dostępne w programie Audacity, ale badacz może też po prostu tworzyć noty (mema) w formie zapisków prowadzonych np. 
w programie MS Word czy OpenOffice Writer, odpowiednio je indeksując i archiwizując. Później będzie mógł je także włączyć do analizy w dowolnym programie komputerowym wspierającym analizę danych jakościowych, takim jak np. WeftQDA ${ }^{3}$. Wspomniany program może bowiem posłużyć do zgrupowania, a następnie przetworzenia wszelkiego rodzaju zapisków wykonanych przez badacza. WeftQDA posiada jednak znacznie większe możliwości, generalnie wspomagając proces opracowywania danych. Spośród dostępnych funkcji należy przede wszystkim wskazać na możliwość: tworzenia bazy danych materiałów tekstowych; przeszukiwania tekstów pod kątem określonych słów; przypisywania kodów do określonych segmentów tekstu; tworzenia drzewa kodów i ich przejrzystej struktury; wyszukiwanie fraz i wyrazów w tekście; przeszukiwania w obrębie kodów; tworzenia notatek $w$ formie memo do zapisywania krótkich informacji bądź myśli analitycznych badacza; funkcje statystyk i tworzenia prostych tablic krzyżowych.

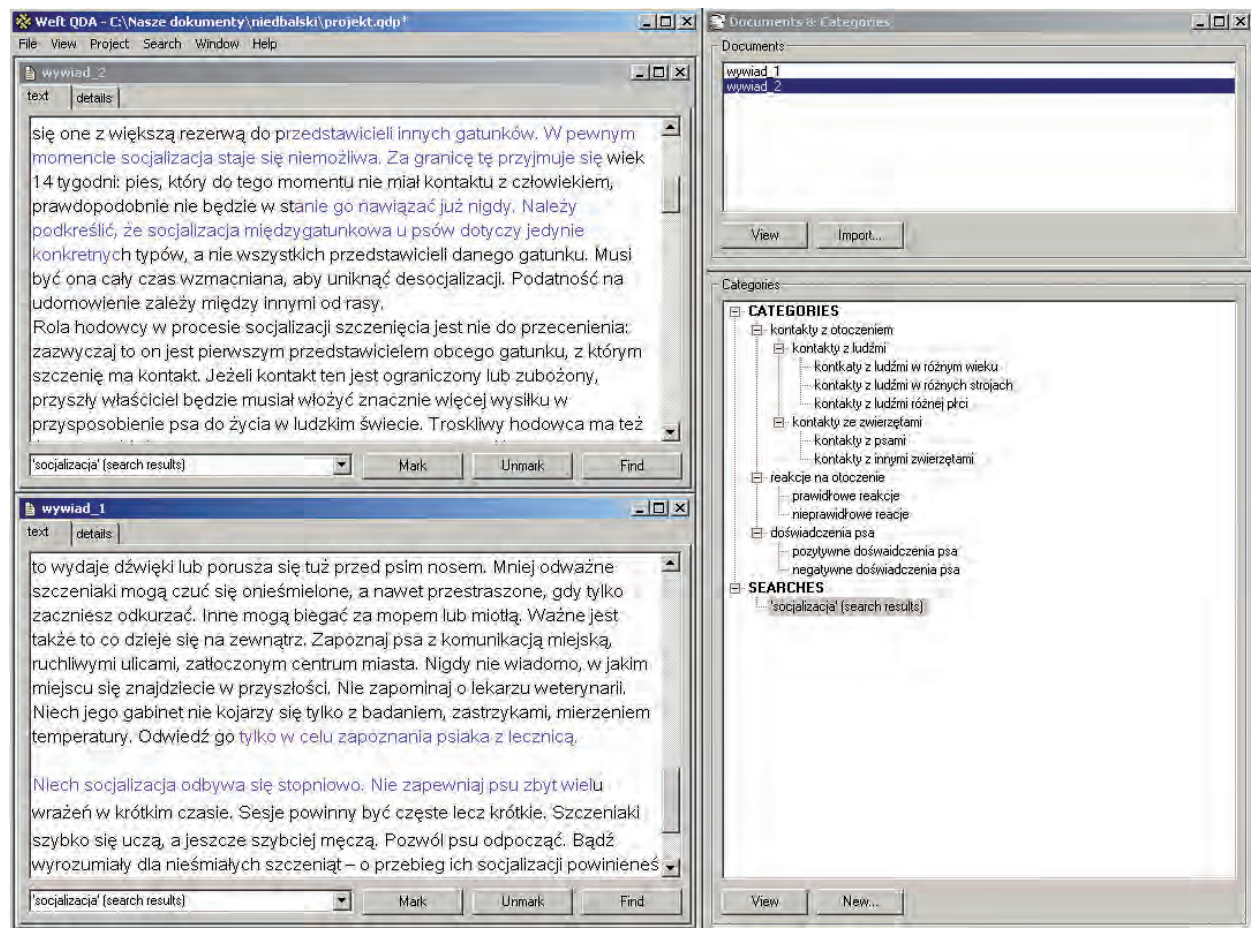

Ilustr. 3. Okna programu WeftQDA

Źródło: opracowanie własne

${ }^{3}$ Program WeftQDA jest darmowym oprogramowaniem rozpowszechnianym na zasadach licencji publicznej, opracowanym przez Alexa Fentona. Program oraz dodatkowe informacje o nim można pobrać ze strony: www.pressure.to/qda/. 
Program posiada bardzo prosty wygląd. Jego autorzy zadbali, aby wszystkie istotne funkcje były dostępne „na wyciągniecie ręki”. W głównym oknie programu u samej góry znajduje się menu główne, gdzie można uzyskać dostęp do większości funkcji. Największą część programu zajmuje okno robocze, w którym wyświetlane są materiały źródłowe, a więc teksty wywiadów, notatek z obserwacji itd. Obok okna głównego znajduje się mniejsze okno projektu (Documents and Categories), w którym będą pojawiać się importowane dokumenty oraz tworzone kategorie. W górnej części tego okna jest umieszczona lista wszystkich dokumentów, które są importowane do projektu. Natomiast dolna część okna przeznaczona jest do wyświetlania „drzewa kategorii”, czyli kategorii zorganizowanych w określonej hierarchicznej strukturze. W drzewie kategorii można także znaleźć zapisane wyniki przeszukiwań i zapytań wygenerowane uprzednio przez badacza (Niedbalski 2013: 86).

Podobnie intuicyjny jest sposób korzystania z poszczególnych opcji. Jednak, jak każdy nowy program, także WeftQDA wymaga pewnej wprawy i przyswojenia kilku najważniejszych zasad związanych z jego obsługą. Zanim będzie można rozpocząć pracę w programie, trzeba pamiętać o następujących kwestiach.

Po pierwsze, należy utworzyć i zapisać nowy projekt, który de facto jest bazą danych, w ramach której gromadzone będę kolejne materiały tekstowe. Dokonujemy tego, korzystając z opcji New Project znajdującej się w menu File.

Po drugie, czynnością, jaką musi wykonać badacz po utworzeniu (lub otwarciu) projektu, jest dodanie dokumentów do bazy danych. Mogą to być transkrypcje wywiadów, notatki z obserwacji terenowych, a także wszelkiego rodzaju teksty pochodzące z artykułów prasowych, ulotek, plakatów itd. Przy czym należy koniecznie wspomnieć, że ograniczeniem programu są dane tekstowe zapisane $\mathrm{w}$ formacie .txt, a więc z pominięciem formatowania. Ponadto $\mathrm{w}$ programie nie ma możliwości edytowania danych, stąd konieczność dokładnego ich sprawdzenia jeszcze przed zaimportowaniem.

Po trzecie, warto odpowiednio zorganizować rozkład okien, ponieważ w ten sposób uzyskujemy znacznie większy komfort pracy, a przy tym wszystkie informacje będą dla nas lepiej widoczne. $W$ tym celu dobrze jest tak ustawić rozmiar okien i ich położenie na ekranie monitora, aby obok okna głównego programu, gdzie wyświetlane są kodowane treści (a także takie informacje, jak mema czy wyniki przeszukiwania danych), znajdowało się obok okna Documents and Categories. Warto dodać, że badacz może skorzystać z opcji ustawień Window, dzięki czemu będzie mógł nie tylko przeglądać kilka dokumentów równocześnie, lecz także dopasować sposób ich wyświetlania do własnych potrzeb. Tak można w wygodny sposób porównywać fragmenty wybranych dokumentów, co znacznie ułatwia proces analityczny w przypadku stosowania metodologii teorii ugruntowanej. 
Po czwarte, użytkownik powinien poznać specyfikę pojęć stosowanych w programie i umieć je przełożyć na język metodologii teorii ugruntowanej. Szczególną uwagę należy zwrócić na dwa z nich. Pierwsze to marking („znakowanie"). Dzięki tej opcji badacz rejestruje połączenie między kategorią i fragmentem tekstu przez „znakowanie” sekcji dokumentu. Procedura ta jest więc kodowaniem. Drugie pojęcie to category („,kategorie”), pod którym kryją się zbiory poszczególnych "oznakowanych”, czyli zakodowanych fragmentów tekstów pochodzących z różnych dokumentów.

Po wykonaniu powyższych czynności i zapoznaniu się ze specyfiką programu można przystąpić do właściwej pracy analitycznej. Zgodnie z metodologią teorii ugruntowanej badacz przede wszystkim powinien skupić się na generowaniu kodów i tworzeniu kategorii oraz w dalszej kolejności powiązań między nimi. Podstawową jednostką analizy w MTU są bowiem fragmenty danych, które mogą przybrać postać „porcji” informacji, wydzielonych ze względu na interesujące badacza kwestie czy szerzej poruszane przez rozmówcę tematy. Strukturalnie mogą to być pojedyncze zwroty, wersy, zdania lub akapity, którym badacz może przypisać określone kody. Te z kolei stanowią swoiste „etykiety” o różnym stopniu skonceptualizowania (Niedbalski 2014). Jak sugeruje Marek Gorzko (2008: 93), kodowanie jest sposobem określenia tego, czego dotyczą analizowane dane. Polega na przypisaniu do jednego lub większej liczby akapitów określonego słowa bądź zwrotu. Kod ma zatem charakter pojęcia, które informacjom opisowym przypisuje.

W programie WeftQDA proces kodowania polega na przypisywaniu określonych fragmentów tekstów danym kategoriom. Najpierw należy zaznaczyć fragment tekstu, a następnie wybrać kategorię, której badacz chce przypisać ową porcję danych. W tym celu należy zaznaczyć określoną kategorię w drzewie kategorii w oknie Documents and Categories, a następnie kliknąć na przycisk Mark („Zaznacz”) w dolnej części okna dokumentu. W ten sposób dany obszar tekstu zostanie oznaczony jako odnoszący się do tej kategorii, natomiast nazwa takiej kategorii pojawi się w oknie aktualnie opracowywanego dokumentu obok przycisku Mark („Zaznacz"). W efekcie zakodujemy wybrany fragment, co zostanie oznaczone zmianą jego koloru z czarnego na niebieski.

Glaser i Strauss (1967: 37) na początku badania rekomendują tworzenie pojęć o niskim stopniu abstrakcji - ogólność generowanych pojęć nie powinna przekraczać ram lokalnych. Na bazie tych pojęć, nieco później, w toku badania pojawiają się dopiero ogólniejsze kategorie (Gorzko 2008: 102). Powstałe w ten sposób kategorie są elementami projektu grupującymi tematy, miejsca, osoby i inne kwestie interesujące badacza.

W programie WeftQDA tworzenie kategorii odbywa się poprzez zaznaczenie określonej kategorii w drzewie kategorii, a następnie naciśnięcie przycisku New... („Nowe”). Po wykonaniu tej czynności pojawi się małe okno dialogowe, w którym 
trzeba wpisać nazwę nowej kategorii i potwierdzić chęć jej utworzenia przyciskiem OK. Nowa kategoria zostanie przyporządkowana jako podrzędna wobec kategorii ostatnio podświetlonej $w$ drzewie kategorii. Jeśli badacz nie zaznaczy danej kategorii, a nowo utworzona kategoria będzie umiejscowiona w niewłaściwym miejscu w drzewie, zawsze można w prosty sposób zmienić jej miejsce. Wystarczy przy pomocy kursora myszki przeciągnąć ją i upuścić na właściwą kategorię nadrzędną. W ten sam sposób - „przeciągania” określonych kategorii - można organizować strukturę drzewa kategorii zgodnie z postępami w pracy analitycznej (Niedbalski 2013: 91).

Według metodologii teorii ugruntowanej wraz z kodowaniem i generowaniem kategorii analitycznych powinien postępować proces pisania not teoretycznych. Noty są zapisem koncepcji badacza związanymi z kodami i służą uściśleniu stosowanych kategorii oraz ukierunkowywaniu procesu kodowania (Weaver, Atkinson 1994; Richards 1999). Jak podaje Graham Gibbs (2011: 68), noty są również swoistym łącznikiem między dwoma etapami analizy - kodowaniem i pisaniem raportu. Pisanie not towarzyszy analitykowi stosującemu metodologię teorii ugruntowanej od początku procesu badawczego (Konecki 2000).

W programie WeftQDA badacz może tworzyć noty (memo), zarówno odnosząc je do całych dokumentów, jak i poszczególnych kategorii. W ten sposób jest w stanie zapisywać różnego rodzaju pomysły i koncepcje dotyczące powiązań między poszczególnymi kodami czy bardziej ogólne hipotezy będące konsekwencją czynionej na bieżąco analizy danych. Aby utworzyć notę, należy kliknąć myszką na daną kategorię bądź nazwę dokumentu w oknie Documents and Categories. W pierwszym przypadku zostaje wyświetlony cały dokument, a w drugim - fragmenty tekstu, które zostały zakodowane wybraną kategorią. W obydwu sytuacjach w nowo otwartym oknie pojawia się również zakładka „details”, gdzie znajduje się pole do zapisu noty.

Dla wyjaśnienia prezentowanych zagadnień posłużymy się przykładem badań dotyczących socjalizacji szczeniaka. Pierwszą czynnością było przeprowadzenie kodowania otwartego, a w międzyczasie dokonywano zmian w strukturze drzewa kodowego, stopniowo układając kategorie w określony sposób, zgodnie z krystalizującą się koncepcją badacza.

Dzięki strukturze drzewa można było oddać stopień hierarchiczności (nadrzędności-podrzędności) pomiędzy kategoriami oraz dzięki wpisaniu w formie not stosownych informacji określić relacje, jakie między nimi występują.

Główne zalecenie twórców metodologii teorii ugruntowanej (Glaser, Strauss 1967) polega na przeprowadzaniu ciągłych porównań, a więc zestawianiu ze sobą fragmentów opisanych podobnym kodem czy porównanie sposobu zakodowania danego przypadku z innym przypadkiem (Charmaz, Mitchell 2001: 165). Na tej bazie generowane są coraz ogólniejsze kategorie wydobywające na jaw tkwiące u podłoża zjawisk wymiary jednorodności (underlying uniformities) (Gorzko 2008: 86). 


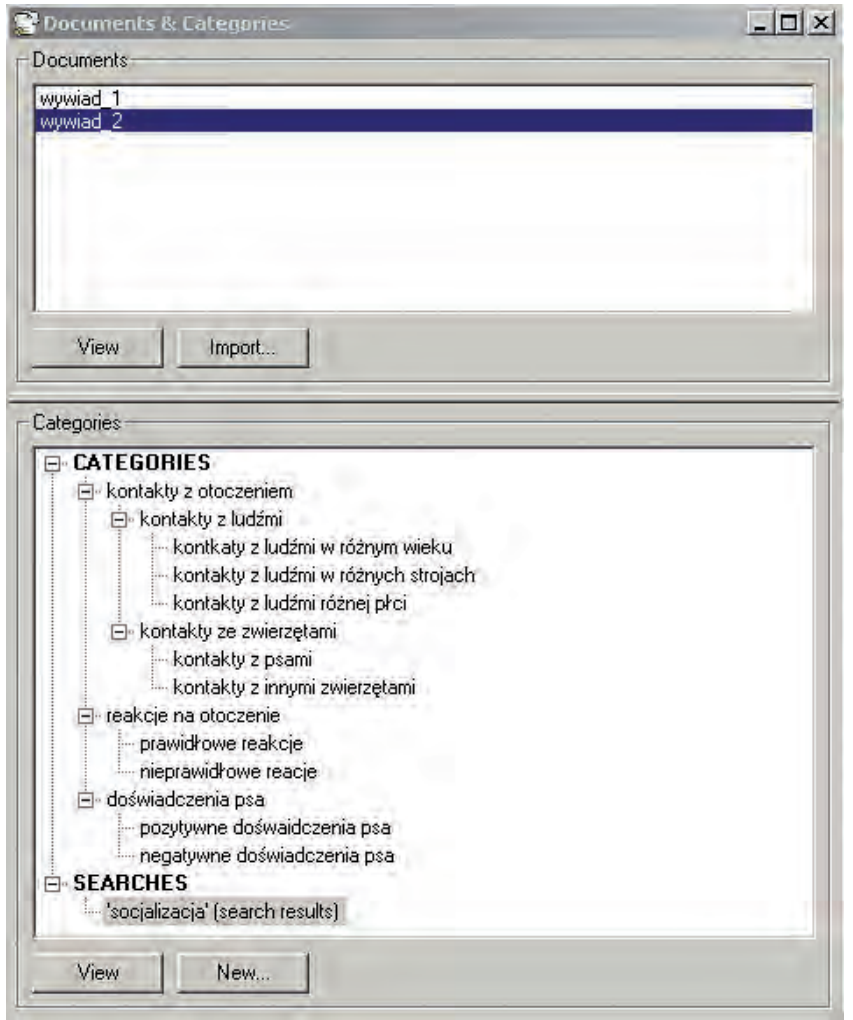

Ilustr. 4. Struktura drzewa kategorii utworzonego w programie WeftQDA

Źródło: opracowanie własne

W praktyce korzystania z oprogramowania WeftQDA procedurę porównania wykonuje się, stosując opcje wyszukiwania danych. Proces ten polega na przeglądaniu fragmentów tekstu oraz innych rodzajów danych, które zostały zakodowane danym kodem. W tym celu należy skorzystać z opcji przeglądania wszystkich sekcji poszczególnych dokumentów zakodowanych za pomocą danych kategorii. Dzięki temu można porównać oraz sprawdzić, co mają wspólnego, a czym się różnią treści, do których zostały przypisane określone kategorie.

Aby zobaczyć segmenty tekstów w poszczególnych dokumentach, które zakodowano daną kategorią, należy odszukać jej nazwę w drzewie kategorii (okno Documents and Categories) i dwukrotnie kliknąć myszką lub wybrać jego nazwę i nacisnąć przycisk View („Widok").

W porównywaniu danych pomocne są także narzędzia przeszukiwania. Mają one istotne znaczenie w procesie porównywania danych zarówno pod względem treści interesujących badacza wątków, jak i konkretnych wygenerowanych już 
kategorii. Przeszukiwanie pozwala też na sprawdzenie, jakie kody mogą ze sobą współwystępować lub wykluczać się. Służą do tego operatory logiczne OR, AND, AND NOT dostępne w opcji Query, która odnosi się do możliwości przeszukiwania zakodowanych treści różnych dokumentów przez dwie lub więcej kategorii bądź fraz z zastosowaniem wymienionych operatorów.

W omawianym przykładzie, socjalizacji szczeniaka, na podstawie wygenerowanych kategorii „kontakty z ludźmi” oraz „negatywne reakcje psa” możemy sprawdzić, czy i w jakich sytuacjach szczeniaki reagują negatywnie wobec określonych kategorii osób, których takie reakcje dotyczą.

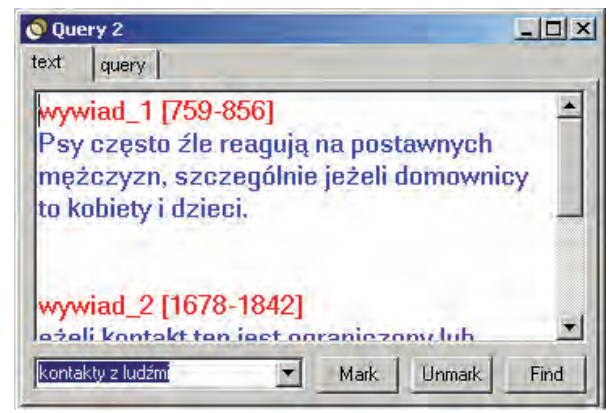

Ilustr. 5. Wyniki przeszukiwania wybranej kategorii w programie WeftQDA

Źródło: opracowanie własne

Analiza treści zakodowanych powyższymi kategoriami fragmentów wywiadów wskazuje, że psy przejawiają zachowania agresywne wobec postawnych mężczyzn, zwłaszcza tych, którzy sami są agresywni tak w stosunku do psa, jak i innych słabszych od siebie osób, m.in. starszych, chorych oraz dzieci.

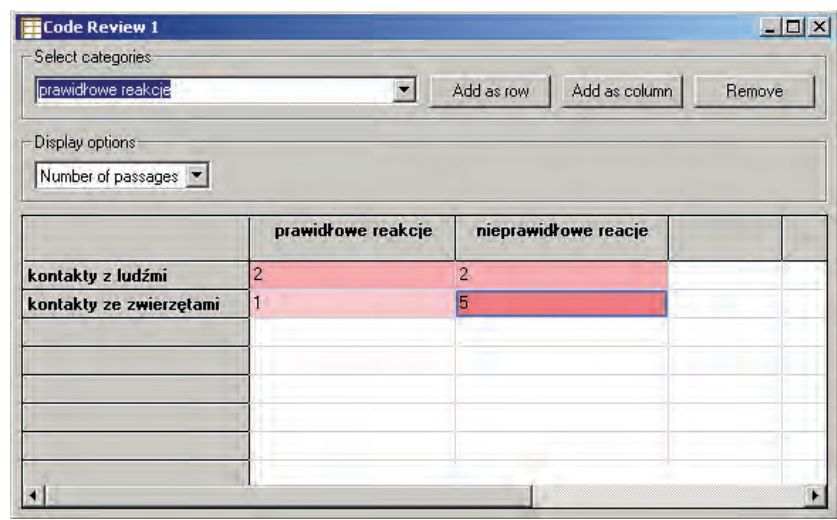

Ilustr. 6. Wyniki zestawienia wybranych kategorii w programie WeftQDA

Źródło: opracowanie własne 
Ponadto program WeftQDA został wyposażony w narzędzie przeszukiwania Code Reviews, które umożliwia tworzenie zestawień kategorii. Funkcja ta daje odpowiedź na pytanie, jak często i w jakim zakresie ten sam tekst (segment tekstu) jest przypisany do określonych kategorii.

Jako zobrazowanie wykorzystania funkcji Code Review można podać przykład, w którym badacz wygenerował kategorie: „kontakty z ludźmi” i „kontakty ze zwierzętami” oraz dwie inne kategorie: „zachowania negatywne” $i$ „zachowania pozytywne". W ten sposób badacz chce sprawdzić, wobec jakiej kategorii aktorów (ludzi czy zwierząt) szczeniak będzie przejawiał określonego rodzaju reakcje (pozytywne czy negatywne).

Na podstawie zestawienia można stwierdzić, że szczeniak częściej reaguje negatywnie w stosunku do innych zwierząt niż wobec ludzi. Sytuacja odwrotna ma natomiast miejsce $w$ przypadku reakcji na ludzi.

Wreszcie narzędzia przeszukiwania mogą też pomóc w „półautomatycznym” kodowaniu. Do tego celu można wykorzystać opcję Search bądź Query. Pierwsza z nich pozwala na przeszukiwanie danych tekstowych pod względem występowania poszukiwanej frazy bądź słowa. Druga zaś oferuje możliwość kwerendy współwystępowania kilku słów kluczowych za pomocą opcji „CONTAINS WORD” („zawiera słowo”). Zarówno w jednym, jak i w drugim przypadku odnalezione zostaną te fragmenty, w których występują poszukiwane słowa. Badacz powinien przejrzeć wszystkie zaznaczone w ten sposób segmenty tekstu i każdorazowo zdecydować, czy poszczególne z nich można zakodować określonym kodem.

Prezentowany program posiada wiele cech, które sprawiają, że może on być stosowany $w$ ramach projektów opartych na procedurach metodologii teorii ugruntowanej. Wystarczy chociażby wspomnieć o opcjach kodowania, tworzenia struktury drzewa, przeszukiwania czy pisania not. Ponadto jego niewątpliwą zaletą jest bezpłatny dostęp oraz łatwość i intuicyjność obsługi, co sprawia, że WeftQDA jest programem praktycznie dla każdego użytkownika. $Z$ drugiej strony program posiada też pewne ograniczenia, które mogą wpłynąć na jego przydatność dla niektórych użytkowników. Przede wszystkim trzeba pamiętać, że WeftQDA nie obsługuje innego tekstu niż .txt, dlatego nie można importować dokumentów bez utraty formatowania. Program wspiera wyłącznie analizę danych tekstowych, stąd nie ma możliwości, by poddać analizie materiały innego typu, np. zdjęcia, audio, wideo. WeftQDA nie pozwala także na wizualizację wyników interpretacji danych, a więc tworzenia wykresów czy diagramów, co w pewnym sensie zubaża analizę i ogranicza kontrolę nad jej przebiegiem. Należy jednak podkreślić, że jako narzędzie rodzaju code-and-retrieve (Bieliński, Iwańska, Rosińska-Kordasiewicz 2007: 93-94) spełnia swoje zadanie w zupełności. Z pewnością jest to program bardzo przydatny dla badaczy chcących efektywnie zorganizować swoje dane i uporządkować nowe informacje będące efektem zarówno pracy terenowej, jak i analitycznej. 


\section{Wizualizacja koncepcji za pomocą programu CmapTools}

Badacz, który prowadzi analizę danych opartą na procedurach metodologii teorii ugruntowanej, bardzo często stara się, prócz kodowania czy tworzenia not teoretycznych, przedstawiać także całościowe lub częściowe wyniki swojej analizy w postaci wizualnej. Najczęściej są to różnego rodzaju mapy pojęciowe, a najważniejszą z nich jest scalający w jedną całość wszystkie wygenerowane kategorie odnoszące się do kategorii centralnej zwaną diagramem integrującym. Tworzone na bieżąco podczas prowadzonej analizy wszelkiego rodzaju wizualne reprezentacje wygenerowanych kategorii, związków i relacji, jakie między nimi występują, pomagają badaczowi w rozpoznaniu się w aktualnym stanie analizy, przez co dużo łatwiej może on ocenić i zweryfikować jej dotychczasowe wyniki. Z kolei diagram końcowy, będący w istocie uwieńczeniem całej analizy przeprowadzonej przez badacza, pomaga innym osobom lepiej zrozumieć sposób i charakter istniejących zależności pomiędzy kategoriami, w istotny sposób ułatwiając wgląd w istotę koncepcji analityka (Gibbs 2011: 154).

Istotą analizy w metodologii teorii ugruntowanej jest wielokrotne modyfikowanie kategorii, powiązań między nimi itd., a więc przebudowywanie koncepcji, stąd diagram, który ma odzwierciedlać wszystkie te elementy projektu, musi być z konieczności na bieżąco zmieniany i uaktualniany. Dlatego ważne jest, aby narzędzia, które mogą służyć do tworzenia takich map, były nie tylko proste w obsłudze, pozwalały na dokładne oddanie koncepcji badacza, a przy tym przedstawiały diagram w jak najbardziej przejrzysty dla wszystkich sposób, ale także pozwalały na łatwe i szybkie jego modyfikowanie. Takie zalety posiada właśnie program CmapTools ${ }^{4}$, który, co istotne, gwarantuje to zupełnie nieodpłatnie.

Program CmapTools pozwala na tworzenie nawet bardzo rozbudowanych i zaawansowanych modeli integrujących, stąd jest wręcz wskazany dla osób posługujących się metodologią teorii ugruntowanej. Daje możliwość prezentowania i rozpowszechnia wyników swoich koncepcji dzięki rozbudowanej funkcji eksportowania oraz przenoszenia danych (Niedbalski 2013: 105).

Pracę z programem rozpoczynamy od utworzenia nowego modelu Cmap. W tym celu należy z głównego menu File („Plik”) wybrać opcję New Cmap (lub użyć skrótu klawiaturowego Ctrl + N). Wykonanie tej operacji spowoduje otwarcie nowego okna o domyślnej nazwie Untitled 1, gdzie cyfra wskazuje każdy kolejny projekt tworzony w programie CmapTools. Teraz możemy przystąpić

${ }^{4} \mathrm{CmapTools} \mathrm{to} \mathrm{program} \mathrm{udostępniony} \mathrm{na} \mathrm{zasadach} \mathrm{licencji} \mathrm{publicznej} \mathrm{przez} \mathrm{Institute} \mathrm{for} \mathrm{Hu}$ man \& Machine Cognition, autorstwa Alberto J. Cañasa; Associate Director \& Senior Research Scientist Inst. for Human \& Machine Cognition; 40 South Alcaniz St., Pensacola, FL 32502. Program oraz dodatkowe informacje o nim można pobrać ze strony: http://cmap.ihmc.us/download/. 
do tworzenia modelu, co odbywa się poprzez dodawanie kolejnych elementów projektu mapy. Czynność tę wykonujemy w następujący sposób. Za pomocą lewego przycisku myszy klikamy dwukrotnie w dowolnym miejscu na obszarze roboczym. Spowoduje to pojawienie się domyślnego kształtu ze znakami zapytania wewnątrz, które należy zastąpić odpowiednią nazwą, jaką chcemy nadać powstałej w ten sposób kategorii. W tym celu wystarczy ponownie kliknąć dwukrotnie lewym przyciskiem myszy w obszarze kształtu, a następnie w miejsce znaków zapytania wpisać właściwą nazwę.

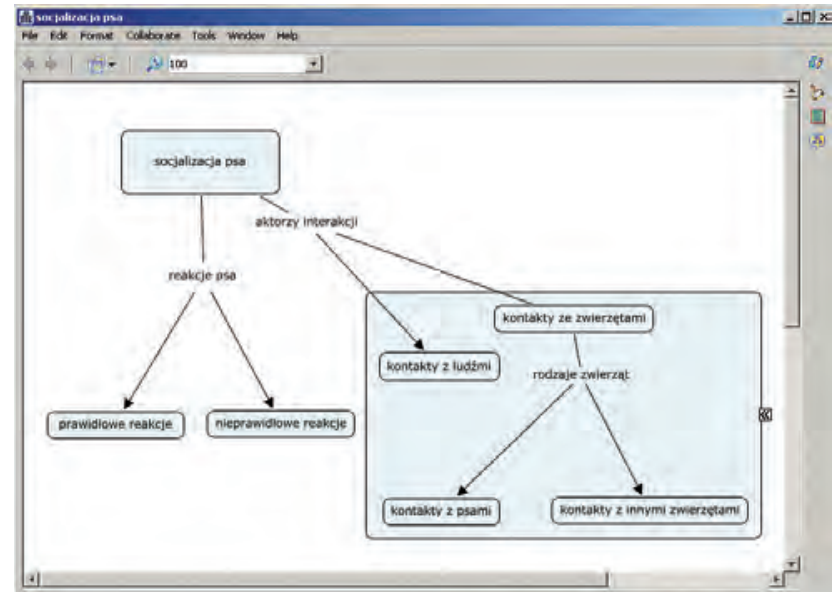

Ilustr. 7. Okno programu CmapTools z otwartą mapą pojęciową

Źródło: opracowanie własne

Ponieważ ideą tworzenia modeli jest ilustracyjne odwzorowanie koncepcji analitycznych badacza, stąd naturalne jest, że każdy element może być połączony z kilkoma innymi kategoriami jednocześnie i zawierać więcej niż jedną frazę je łączącą. W tym celu należy przeciągnąć strzałkę pomiędzy wybranymi elementami i nadać nazwę tak utworzonemu połączeniu (związkowi kategorii), co spowoduje utworzenie powiązania pomiędzy elementami projektu reprezentującymi określone kategorie (Niedbalski 2013: 110).

Rozbudowane mapy, a takimi z reguły są diagramy integrujące, mogą zawierać szereg elementów, przez co zdarza się, że przestają być czytelne. Ale i w tym przypadku z pomocą przychodzi CmapTools, bowiem został on wyposażony w poręczne narzędzia „zagnieżdżania” kategorii oraz łączenia elementów w ramach różnych diagramów. W pierwszym przypadku, aby utworzyć takie zgrupowanie elementów modelu (jak pamiętamy, reprezentujących określone kategorie w naszej koncepcji), musimy, klikając lewym przyciskiem myszy z wciśniętym klawiszem Ctrl, zaznaczyć interesujące nas składniki modelu (można wybrać wszystkie składniki modelu, 
naciskając kombinację klawiszy $\mathrm{Ctrl}+\mathrm{A}$ ), a następnie naciskając na prawy przycisk myszy w rozwiniętym menu kontekstowym wybrać opcję Nested Node/Create. W przypadku drugim wystarczy otworzyć dwa zapisane $w$ folderach programu projekty modeli, wybrać w jednym z nich określony element, a następnie klikając przyciskiem myszy, przeciągnąć linię, która ma połączyć ów element z innym elementem znajdującym się $w$ drugim modelu (Niedbalski 2013: 122).

W omawianym przykładzie badań dotyczących socjalizacji psa mapa koncepcyjna została podzielona na kilka pomniejszych - dzięki możliwości operowania w programie CmapTools na kilku odrębnych mapach, w których jednak poszczególne elementy można ze sobą łączyć - dając w ten sposób możliwość znacznie bardziej przejrzystej struktury opartej na wydzielonych kategoriach nadrzędnych.

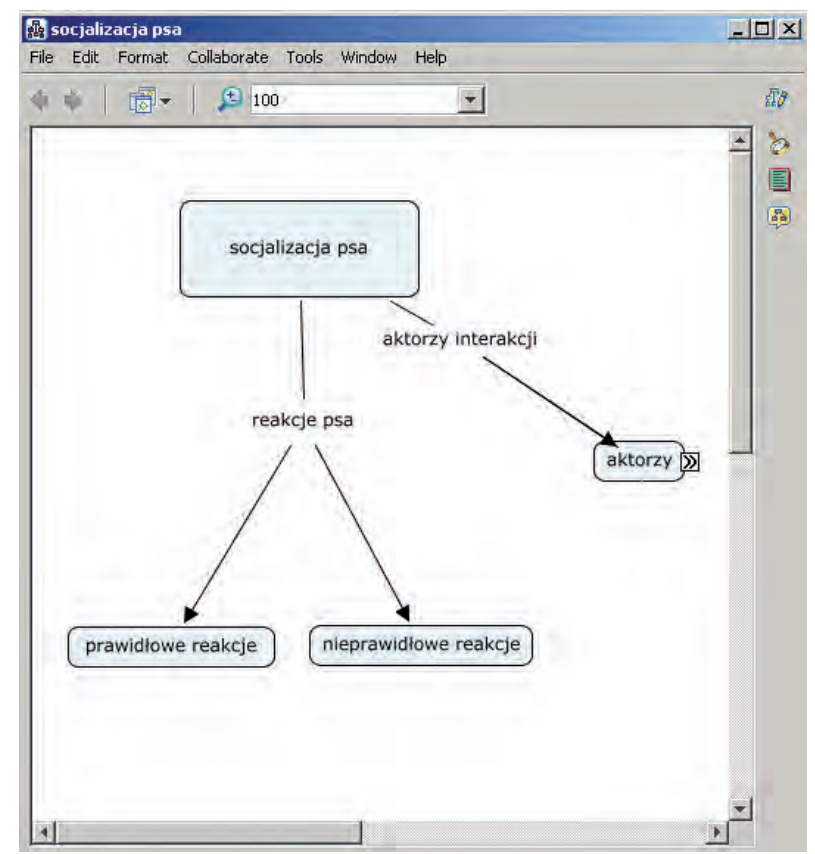

Ilustr. 8. Przykład użycia opcji „zagnieżdżania” elementów mapy pojęciowej wykonanej w programie CmapTools

Źródło: opracowanie własne

Przejrzystości, a przy tym sposobności oddania dokładniejszej charakterystyki powiązań i zależności między różnymi elementami mapy, służyć mogą opcje ich edycji. W ich ramach otrzymujemy możliwość zmiany formatu linii, kształtów, czcionki itd. Ponadto w obrębie konstruowanych modeli daje się wprowadzać różnego rodzaju pliki graficzne dopełniające i ilustrujące prezentowane koncepcje, a jednocześnie wzbogacające wizualnie dany projekt mapy pojęciowej 
(Niedbalski 2013: 130-137). Wprowadzenie takich elementów wizualnych odbywa się w prosty sposób, wykorzystujący mechanizm polegający na przeciągnięciu wybranej przez nas ilustracji i jej upuszczeniu na dowolny element mapy.

Na koniec warto jeszcze wspomnieć o możliwości wyeksportowania danych i całych diagramów w postaci m.in. zdjęć w formacie jpg, które można następnie zamieścić jako ilustracje w raporcie lub innego rodzaju publikacji. Opcja ta powoduje, że tworzone w programie mapy i diagramy nie tylko mogą służyć w pracy analityka, ale także stanowić doskonałe źródło rycin wzbogacających teksty prac i publikacji.

CmapTools jako narzędzie pomocne w pracy badacza jakościowego posiada kilka istotnych zalet. Przede wszystkim program ten jest z założenia przeznaczony do konstruowania map pojęciowych oraz interpretacji danych za pomocą diagramów, porządkowania i integrowania kodów, a także graficznego rekonstruowania analizowanych procesów. Z pewnością $w$ tym zakresie zaspokoi oczekiwania nawet dość wymagających użytkowników. CmapTools z pewnością będzie doskonałym programem zarówno jako podstawowe narzędzie pracy analityka, jak i uzupełnienie oprogramowania WeftQDA, które nie posiada funkcji wizualizacji danych i tworzenia diagramów integrujących (Niedbalski 2013: 180).

\section{Podsumowanie}

Artykuł ma za zadanie przede wszystkim wprowadzić czytelników w tematykę CAQDAS oraz pokazać sposób stosowania popularnych i dostępnych bezpłatnie programów komputerowych, dzięki którym możliwy staje się proces przygotowania i przeprowadzenia projektu badawczego opartego na metodologii teorii ugruntowanej. $Z$ tego względu zaprezentowane zostały te opcje oprogramowania, które w największym stopniu ów proces wspomagają.

W przypadku Audacity mamy możliwość skorzystania z opcji obróbki materiałów dźwiękowych, związanych głównie z transkrypcją plików audio. Zaprezentowane funkcje służą usprawnieniu procesu przepisywania odsłuchiwanych nagrań, ale także poprawie ich jakości.

Właściwą analizę możemy natomiast prowadzić przy pomocy programu WeftQDA, oferującego zestaw narzędzi do pracy z dokumentami tekstowymi. Program ten nie został zaprojektowany pod kątem jego zastosowania do konkretnej metody badawczej, jednak ze względu na wspieranie takich działań, jak kodowanie, sortowanie, kategoryzowanie i przeszukiwanie danych, może być z powodzeniem wykorzystany przez badaczy stosujących MTU.

$Z$ kolei program CmapTools to wszechstronne narzędziem służące do tworzenia map pojęciowych, a także prezentowania danych w formie graficznej. Z tego względu jest to program dla osób, które potrzebują wizualizować swoje 
koncepcje analityczne bądź po prostu usprawnić proces interpretacyjny danych. CmapTools umożliwia tworzenie rozbudowanych i zaawansowanych modeli integrujących, porządkowanie i integrowania kodów, a także graficzne rekonstruowanie analizowanych procesów.

Należy pamiętać, że pomimo tak wielu pomocnych opcji, jakie posiadają prezentowane programy, a także ich wzajemnego uzupełniania się, nie są to rozwiązania idealne i pozbawione wad (Niedbalski, Ślęzak 2012). Niemniej potencjalne korzyści, jakie badacz może odnieść przy ich zastosowaniu powodują, że są to rozwiązania godne polecenia. I nawet jeśli początkowo nieco czasu będzie wymagało ich poznanie, to warto jest zdobyć się na taki wysiłek, który w przyszłości może procentować znacznie sprawniejszą i bardziej efektywną pracą badacza (Lofland i in. 2010: 144-145; Kubinowski 2010: 73-77).

\section{Bibliografia}

Bielecka-Prus Joanna (2013), Transkrypcja jako działanie interpretacyjne, referat wygłoszony podczas II Transdyscyplinarnego Sympozjum Badań Jakościowych, 10-12 czerwca, Łódź.

Bieliński Jacek, Iwańska Katarzyna, Rosińska-Kordasiewicz Anna (2007), Analiza danych jakościowych przy użyciu programów komputerowych, "ASK. Społeczeństwo. Badania. Metody”, $\mathrm{nr} 16, \mathrm{~s} .89-114$.

Charmaz Kathy (2009), Teoria ugruntowana. Praktyczny przewodnik po analizie jakościowej, PWN, Warszawa.

Charmaz Kathy, Mitchell Richard G. (2001), Grounded Theory in Ethnography, [w:] Paul Atkinson $i$ in. (eds), Handbook of Ethnography, Sage, London.

Frankfort-Nachmias Chava, Nachmias David (2001), Metody badawcze w naukach społecznych, Wydawnictwo Zysk i Spółka, Poznań.

Gibbs Graham (2011), Analizowanie danych jakościowych, przeł. Maja Brzozowska-Brywczyńska, PWN, Warszawa.

Glaser Barney G. (1978), Theoretical Sensitivity, The Sociology Press, San Francisco.

Glaser Barney G., Strauss A. L. (1967), The Discovery of Grounded Theory. Strategies for Qualitative Research, Aldine Publishing Company, Chicago.

Gorzko Marek (2008), Procedury i emergencja. O metodologii klasycznych odmian teorii ugruntowanej, Wydawnictwo Naukowe Uniwersytetu Szczecińskiego, Szczecin.

http://audacity.sourceforge.net/download/ [dostęp: 1.03.2014].

http://cmap.ihmc.us/download/ [dostęp: 1.03.2014].

Konecki Krzysztof (2000), Studia z metodologii badań jakościowych. Teoria ugruntowana, PWN, Warszawa.

Konecki Krzysztof (2008), Wizualna teoria ugruntowana. Rodziny kodowania wykorzystywane w analizie wizualnej, „Przegląd Socjologii Jakościowej”, t. 4, nr 3, s. 89-115; www.przegladsocjologiijakosciowej.org [dostęp: 20.11.2013].

Kubinowski Dariusz (2010), Jakościowe badania pedagogiczne: filozofia-metodyka-ewaluacja, Wydawnictwo UMCS, Lublin. 
Lofland John, Snow David A., Anderson Leon, Lofland Lyn H. (2010), Analiza układów społecznych. Przewodnik metodologiczny po badaniach jakościowych, przeł. Anna Kordasiewicz, Sylwia Urbańska, Monika Żychlińska, Wydawnictwo Naukowe Scholar, Warszawa.

Łobocki Mieczysław (1978), Metody badań pedagogicznych, PWN, Warszawa.

Niedbalski Jakub (2013), Odkrywanie CAQDAS. Wybrane bezpłatne programy komputerowe wspomagajqce analizę danych jakościowych, Wydawnictwo Uniwersytetu Łódzkiego, Łódź.

Niedbalski Jakub (2014), Komputerowe wspomaganie analizy danych jakościowych. Zastosowanie oprogramowania NVivo i Atlas.ti w projektach badawczych opartych na metodologii teorii ugruntowanej, Wydawnictwo Uniwersytetu Łódzkiego, Łódź.

Niedbalski Jakub, Ślęzak Izabela (2012), Analiza danych jakościowych przy użyciu programu NVivo a zastosowanie procedur metodologii teorii ugruntowanej, „Przegląd Socjologii Jakościowej", t. 8, nr 1, s. 126-165; www.przegladsocjologiijakosciowej.org [dostęp: 1.03.2014].

Rapley Tim (2010), Analiza konwersacji, dyskursu i dokumentów, przeł. Anna Gąsior-Niemiec, Wydawnictwo Naukowe PWN, Warszawa.

Richards Lyn (1999), Using NVivo in Qualitative Research, Sage, London-Los Angeles.

Strauss Anselm L., Corbin Juliet (1990), Basics of Qualitative Research, Sage, London-New Delhi. Sztumski Janusz (1979), Wstęp do metod i technik badań społecznych, Uniwersytet Śląski, Katowice. Weaver Anna, Atkinson Paul (1994), Microcomputing and Qualitative Data Analysis, Abebury, Aldershot.

www.pressure.to/qda/ [dostęp: 1.03.2014].

\section{Practical Application of CAQDA Software in Qualitative Research - an Outline of Problems from Perspective of a Research Project Based on Methodology of Grounded Theory}

Summary. Purpose of this article is to present how computer tools may be applied to support analysis of qualitative data in research practice. The author tries to present on a particular example of a research project, the manner of analyzing research in accordance with procedures of the grounded theory methodology, using available functions of programs such as Audacity, WeftQDA and CmapTools. Therefore, a workshop of a qualitative researcher, who uses computer software that aids the research process on a daily basis, is presented. This article presents the manner, in which the analytical process is formed in a context of a chosen method and with application of particular computer software. Simultaneously, the author indicates existing advantages but also consequences of using such software, as well as potential difficulties of CAQDA application in qualitative research. This article is of illustrative and educational character, which allow to familiarize readers with possibilities of CAQDA tools, as well as with their actual usage in realization of research projects based on qualitative methods.

Keywords: computer analysis of qualitative data, CAQDA, methods of qualitative research, methodology of grounded theory, Audacity, WeftQDA, CmapTools. 